\title{
PENGARUH AKTIVITAS PERUSAHAAN TERHADAP PROFITABILITAS DAN PELUANG INVESTASI PADA PERUSAHAAN SEKTOR INDUSTRI BARANG KONSUMSI YANG GO-PUBLIC DI INDONESIA
}

\author{
LCA. Robin Jonathan'1), Theresia Militina2) \\ 1)Fakultas Ekonomi, Universitas 17 Agustus 1945 Samarinda, Samarinda \\ 2)Fakultas Ekonomi dan Bisnis, Universitas Mulawarman, Samarinda
}

\begin{abstract}
Abstrak
Penelitian ini bertujuan untuk menganalisis pengaruh aktivitas perusahaan yang diproyeksikan dalam variabel Total Asset Turn Over (TATO), Inventory Turn Over (ITO), Fixed Asset Turn Over (FATO), dan Working Capital Turn Over (WCTO) terhadap profitabilitas (Return on Asset/ROA) dan peluang investasi pada perusahaan go public di sektor industri barang konsumsi di Indonesia pada tahun 2013-2015. Data penelitian bersumber dari laporan keuangan dari 37 perusahaan yang digunakan sebagai sampel penelitian yang terdiri dari subsektor makanan dan minuman (17 emiten), rokok/tembakau ( 4 emiten), farmasi ( 9 emiten), kosmetik \& keperluan rumah tangga (4 emiten), dan peralatan rumah tangga ( 3 emiten). Data dianalisis menggunakan analisis regresi linear berganda dan analisis jalur. Hasil penelitian menunjukkan bahwa secara simultan aktivitas perusahaan berpengaruh signifikan terhadap ROA dan ROA berpengaruh signifikan dalam memediasi pengaruh TATO terhadap peluang investasi. Namun, ITO, FATO, dan WCTO tidak berpengaruh signifikan terhadap ROA maupun peluang investasi.
\end{abstract}

Kata Kunci : aktivitas perusahaan, profitabilitas, peluang investasi

\begin{abstract}
This study aims to analyze the effect of company activity that projected in four variables, i.e., Total Asset Turn Over (TATO), Inventory Turn Over (ITO), Fixed Asset Turn Over (FATO), and Working Capital Turn Over (WCTO) on profitability (Return on Asset/ROA) and investment opportunity in the public companies in Indonesia incorporated in the consumer goods industry sector during the period of 2013-2015. The research data were sourced from the company financial reports taken from 37 companies as the research sample that consist of the following industry sub-sectors: food and beverage (17 issuers), cigarettes/tobacco (4 issuers), pharmaceuticals (9 issuers), cosmetics and household needs (4 issuers), and household appliances (3 issuers). Data were analyzed using multiple linear regression and path analysis. The results showed that simultaneously company activity has a significant effect on ROA and ROA significantly mediates the effect of TATO on investment opportunity. However, ITO, FATO, and WCTO have no significant effects on ROA or investment opportunity.
\end{abstract}

Keywords : company activity, investment opportunity, profitability. 


\section{Pendahuluan}

Sektor industri barang konsumsi memproduk kebutuhan pokok sehari-hari dengan kapitalisasi pasar kedua terbesar di Indonesia setelah sektor keuangan. Sektor ini relatif stabil dari fluktuasi ekonomi karena masyarakat membutuhkannya. Sektor industri barang konsumsi yang go public (www.idx.co.id) terdiri dari subsektor makanan dan minuman (21 emiten), rokok/tembakau (4 emiten), farmasi (10 emiten), kosmetik \& keperluan rumah tangga (5 emiten), dan peralatan rumah tangga (4 emiten).

Seiring dengan membaiknya kondisi perekonomian, konsumsi masyarakat juga turut meningkat sehingga mendorong peningkatan penjualan emiten sektor industri barang konsumsi. Terlebih lagi jumlah penduduk Indonesia yang mencapai lebih dari 260 juta jiwa, prospek bisnis bidang barang konsumsi tergolong sangat potensial.

Sukamulijana (2017:286) berpendapat bahwa ditinjau dari sisi pengeluaran rumah tangga berpengahasilan rendah (kurang dari Rp.3juta) di Indonesia cenderung mengalokasikan pendapatan rumah tangga bulanan mereka untuk kebutuhan dasar sebesar 27 - 42\% dari pendapatannya. Ini berdampak pada permintaan akan barang konsumsi, artinya prospek bisnis industry barang konsumsi ini akan semakin tinggi.

Perusahaan selalu menginginkan adanya pertumbuhan yang terus menerus, namun juga harus memperhatikan kemampuan perusahaan memperoleh laba (Hanafi dan Halim, 2016). Pertumbuhan perusahaan mencerminkan keberhasilan perusahaan. Pertumbuhan perusahaan dapat terlihat pada peningkatan total asset yang dimiliki. Semakin tinggi investasi yang dilakukan pada asset menunjukkan semakin tinggi pula pertumbuhan perusahaan. Pertumbuhan yang tinggi mencerminkan keberhasilan investasi dimasa yang lalu dan mendorong perusahaan untuk melakukan investasi kembali dimasa yang akan datang. Faktor pendukung untuk melakukan investasi adalah adanya kesempatan yang besar untuk memperoleh keuntungan dari investasi (Fahmi, 2015).
Dengan demikian, perusahaan cenderung akan menahan sebagian dari pendapatan dan keuntungannya untuk investasi guna meningkatkan pertumbuhan perusahaan.

Alma (2001:23) mengatakan bahwa tujuan lain dari bisnis ialah untuk memperoleh keuntungan dari aktivitas perusahaan guna menjaga kelangsungan usahanya. Kegiatan utama dalam pencapaian tujuan adalah melakukan efisiensi terhadap penggunaan asset dalam menghasilkan penjualan, efisiensi penggunaan dana pada persediaan, efektivitas penggunaan aktiva tetap dan modal kerja dalam menghasilkan penjualan.

Halim (2015:214) menegaskan bahwa terdapat beberapa digunakan untuk mengukur seberapa efektif perusahaan dalam memanfaatkan sumber daya yang dimilikinya. Makin tinggi rasio ini menunjukkan makin efisien penggunaan asset dan makin cepat pengembalian dana dalam bentuk kas. Rasio aktivitas terdiri dari: (a) Total Asset Turnover. Menurut Brigham (1992:54) mengukur pergantian semua aset perusahaan. Itu dihitung dengan membagi penjualan dengan total aset; (b) Inventory Turnover. Titman, et al (2018:118) rasio perputaran persediaan sama dengan harga pokok penjualan dibagi dengan investasi perusahaan. Alwi (1991:98) juga mengatakan inventory turnover mengukur efisiensi pengelolaan persediaan barang dagangan; (c) Fixed Asset Turn Over. Menurut Brigham (1992:53) rasio perputaran aktiva tetap mengukur seberapa efektif perusahaan menggunakan pabrik dan peralatannya. Ini adalah rasio penjualan terhadap aktiva tetap bersih. Rasio ini mengukur keefektifan penggunaan dana yang tertanam pada aset tetap dalam rangka menciptakan pendapatan (Brealey, 1991). Makin efektif penggunaan asset tetap dalam rangka menciptakan pendapatan, makin tinggi kemampuan perusahaan menciptakan keuntungan dan berdampak terhadap meningkatnya peluang investasi; (d) Working Capital Turnover. Alwi (1991:98) menegaskan bahwa rasio ini mengukur aktivitas bisnis terhadap kelebihan aktiva lancar atas kewajiban lancar serta menunjukkan banyaknya penjualan yang diperoleh dari padanya. 
Selanjutnya rasio kemampulabaan digunakan untuk mengukur sampai seberapa besar efektivitas manajemen dalam mengelola asset dan equity yang dimiliki perusahaan untuk menghasilkan laba. Makin tinggi rasio ini makin baik, makin tinggi efektivitas penggunaan asset. Shapiro (1991:751) menyatakan pengembalian total aset sama dengan pengembalian setelah pajak atas total aset. Rasio ini digunakan untuk mengukur efektivitas manajemen secara keseluruhan yang ditujukan oleh besar kecilnya tingkat keuntungan yang diperoleh dalam hubungannya dengan penjualan maupun investasi. Makin baik rasio profitabilitas, makin baik kemampuan perusahaan dalam perolehan keuntungan dari asset yang dimiliki. Ini berdampak pada meningkatnya peluang investasi (Brealey, 1991).

Selain itu rasio Pertumbuhan perusahaan menurut Rozeff (dalam Hery, 2017: 61) merupakan tolok ukur bagi keberhasilan perusahaan. Tingginya pertumbuhan perusahaan mencerminkan keberhasilan investasi dimasa lalu dan mendorong perusahaan untuk melakukan investasi kembali dimasa yang akan datang. Dalam meningkatkan pertumbuhan, perusahaan senantiasa membutuhkan dana yang tidak sedikit. Dana ini sebagian diperoleh melalui pendapatan yang dihasilkan dan kegiatan operasional perusahaan. Perusahaan yang memiliki peluang investasi (diukur dengan rasio laba ditahan dengan total aset) yang tinggi cenderung akan menyisihkan sebagian dari pendapatan dan keuntungan sebagai laba yang ditahan dengan tujuan untuk menghindari biaya pendanaan eksternal.

Tujuan penelitian untuk menganalisis dan mengetahui pengaruh aktivitas perusahaan terhadap profitabilitas dan peluang investasi pada perusahaan sector industri barang konsumsi yang go public di Indonesia. Rumusan hipotesis penelitian, meliputi : (a) rasio aktivitas: total asset turnover, inventory turnover, fixed asset turnover dan working capital turnover secara parsial berpengaruh signifikan terhadap profitabilitas (ROA); (b) rasio aktivitas: total asset turnover, inventory turnover, fixed asset turnover dan working capital turnover dan ROA secara parsial berpengaruh signifikan terhadap peluang investasi; (c) rasio aktivitas: total asset turnover, inventory turnover, fixed asset turnover dan working capital turnover secara parsial berpengaruh signifikan terhadap peluang investasi melalui ROA

\section{Metodologi}

Penelitian ini mengkhususkan pada aktivitas perusahaan sebagai variabel independen diproyeksikan dalam total activa turnover, inventory turnover,fixed asset turn over dan working capital turn over terhadap profitabilitas dan peluang investasi sebagai variabel dependen pada sector industri barang konsumsi yang go public di Indonesia.

Populasi sektor industri barang konsumsi yang go public terdiri atas 5 (lima) subsektor, diteliti laporan keuangan pada kurun waktu yang sama, sebanyak 44 emiten. Selanjutnya dengan teknik purposive sampling, jumlah sampel sebanyak 37 emiten.

Model regresi linier berganda digunakan untuk menguji hubungan linier variabel dependen dan variabel independen. Model ini dikatakan baik jika memenuhi asumsi normalitas, linieritas serta bebas dari masalah-masalah asumsi klasik. Uji asumsi klasik menggunakan uji multikolinieritas dan heteroskedastisitas (Abrams, 2010; Olobatuyi, 2006; Gozali dan Fuad, 2008). Untuk menguji kelayakan variabel mediasi (Suliyanto,2011:198) digunakan model product of coefficient (uji Sobel). Dikatakan layak jika nilai $Z_{\text {hitung }}>Z_{\text {table }}$ pada $\alpha=5 \%$.

Analisa jalur digunakan untuk mengetahui hubungan kausal antar variabel guna mengetahui pengaruh langsung dan tidak langsung variabel penyebab terhadap sebuah variabel akibat (Rutherford, dalam Pardede dan Manurung, 2014:16). Langkah-langkah dalam analisa jalur:

a. Menentukan diagram jalur berdasarkan paradigma hubungan linier.

b. Menentukan persamaan struktural, yaitu:

Persamaan substruktur 1

$\mathrm{Y}_{1}=\mathrm{PY}_{1} \mathrm{X}_{1}+\mathrm{PY}_{1} \mathrm{X}_{2}+\mathrm{PY}_{1} \mathrm{X}_{3}+\mathrm{PY}_{1} \mathrm{X}_{4}+\mathrm{e}_{1}$

Persamaan substruktur 2

$\mathrm{Y}_{2}=\mathrm{PY}_{2} \mathrm{X}_{1}+\mathrm{PY}_{2} \mathrm{X}_{2}+\mathrm{PY}_{2} \mathrm{X}_{3}+\mathrm{PY}_{2} \mathrm{X}_{4}+\mathrm{PY}_{2} \mathrm{Y}_{1}+\mathrm{e}_{2}$

c. Tahapan analisis 


\section{Hasil dan Pembahasan}

Persamaan substruktur 1:

$\mathrm{Y}_{1}=\mathrm{PY}_{1} \mathrm{X}_{1}+\mathrm{PY}_{1} \mathrm{X}_{2}+\mathrm{PY}_{1} \mathrm{X}_{3}+\mathrm{PY}_{1} \mathrm{X}_{4}+\mathrm{e}_{1}$

Dimana $\mathrm{Y}_{1}=$ Profitabilitas $(\mathrm{ROA}), \mathrm{X}_{1}=$ Total asset turn over, $X_{2}=$ Inventori turn over, $X_{3}=$ Fixed asset turn over, dan $\mathrm{X}_{4}=$ working capital turn over, $\mathrm{P}=$ Beta standardized, $\mathrm{e}_{1}=$ error.

Uji normalitas dengan menggunakan model Kolmogorov-Smirnov test dimaksudkan untuk menguji apakah nilai residual yang telah distandarisasi pada model regresi berdistribusi normal. Model telah berdistribusi normal jita nilai sig > alpha $5 \%$. Hasil penelitian menunjukkan asymp. Sig $0,055>0,05$. Ini berarti data berdistribusi normal (Ghozali, $2012: 45$ ).

LM-Test digunakan untuk mengukur linieritas yaitu dengan membandingkan nilai $\mathrm{X}^{2}$ hitung $\left(n \times R^{2}\right)$ dengan nilai $X^{2}$ tabel dengan $d f=(n, \alpha)$. Diperoleh nilai $\mathrm{R}^{2}$ sebesar 0,015 sehingga nilai $\mathrm{X}^{2}$ sebesar $0,015 \times 111=1,667$ sedangkan $\mathrm{X}^{2}$ tabel dengan df 0,05, 111 sebesar 124,342. Dengan demikian dapat disimpulkan bahwa nilai $X^{2}$ hitung $(1,667)<$ nilai $X^{2}$ tabel $(124,342)$ maka model regresi benar adalah linier.

\section{Uji Asumsi Klasik Substruktur 1}

Uji Multikolinieritas dengan menggunakan pendekatan nilai Tolerance yang lebih besar dari 0,10 dan Variance Inflation Factor (VIF) tidak lebih dari 10. Diperoleh nilai Tolerance $>$ 0,10 dan nilai VIF $<10$. Ini berarti bahwa model regresi yang terbentuk tidak mengalami gejala multikolinearitas. Uji Heteroskedastisitas dengan metode Glejser dilakukan dengan meregresikan semua variabel bebas terhadap nilai mutlak residualnya memiliki sig $>0,05$. Diperoleh bahwa variabel bebas tidak signifikan pada $\alpha=$ 0,05 terhadap nilai mutlak residualnya, model regresi tidak terjadi masalah heteroskedastisitas.

Regresi linier berganda.

Uji koefisien determinasi $\left(\mathrm{R}^{2}\right)$ menggambarkan besarnya kontribusi variabel bebas terhadap variabel tergantung. Makin tinggi koefisien determinasi, makin tinggi kemampuan variabel bebas menjelaskan variasi perubahan pada variabel tergantung. Hasil penelitian menunjukkan (Model Summary) bahwa model regresi yang digunakan menjelaskan pengaruh variabel bebas terhadap variabel tergantung sebesar $18,80 \%$ dan $90,11 \%$ berhubungan dengan variabel diluar model yang digunakan.

Uji $\mathrm{F}$ digunakan untuk menguji pengaruh variabel bebas terhadap variabel tergantung. Jika nilai $\mathrm{F}_{\text {hitung }}>$ nilai $\mathrm{F}_{\text {table, }}$ variabel bebas memiliki pengaruh secara simultan terhadap variabel tergantung dan model masuk dalam criteria cocok atau fit. Hasil Anova menunjukkan bahwa nilai $F_{\text {hitung }}(6,128)>F_{\text {tabel }}$ $(2,643)$ pada alpha 5\%. Ini berarti bahwa model yang digunakan cocok untuk menjelaskan pengaruh variabel bebas terhadap variabel tergantung secara simultan.

Uji t digunakan untuk menguji secara partial pengaruh variabel bebas terhadap variabel tergantung. Pengaruh signifikansi ditunjukkan oleh besaran nilai $t_{\text {hitung }}>t_{\text {tabel }}$ pada alpha $5 \%$. Hasil penelitian menunjukkan bahwa variabel bebas tatoX1 memiliki nilai thitung $(3,669)>$ $t_{\text {tabel }}(1,984)$ pada alpha $5 \%$. Ini menunjukkan bahwa variabel tato_X1 berpengaruh signifikan terhadap ROA. Sedangkan variabel bebas lainnya memiliki nilai $t_{\text {hitung }}<t_{\text {tabel }}$ pada alpha $5 \%$. Berdasarkan persamaan substruktur 1, diperoleh hasil pengujian hipotesis 1, seperti pada Tabel 1 hasil pengujian hipotesis 1 .

Tabel 1. Hasil Pengujian Hipotesis 1

\begin{tabular}{lcccc}
\hline \multicolumn{1}{c}{ Variabel } & $\mathrm{P}$ & $\mathrm{T}$ & Sig & Ket \\
\hline TATO & 0.392 & 3.669 & 0.000 & Diterima \\
ITO_X2 & 0.171 & 1.936 & 0.056 & Ditolak \\
FATO_X3 & -0.009 & -0.085 & 0.932 & Ditolak \\
WCTO_X4 & -0.071 & -0.809 & 0.420 & Ditolak \\
\hline
\end{tabular}

Sumber : data diolah, 2019

Persamaan substruktur 2:

$\mathrm{Y}_{2}=\mathrm{PY}_{2} \mathrm{X}_{1}+\mathrm{PY}_{2} \mathrm{X}_{2}+\mathrm{PY}_{2} \mathrm{X}_{3}+\mathrm{PY}_{2} \mathrm{X}_{4}+\mathrm{PY}_{2} \mathrm{Y}_{1}+\mathrm{e}_{2}$

dimana $\mathrm{Y}_{2}=$ Peluang investasi, $\mathrm{Y}_{1}=$ Profitabilitas (ROA), $\mathrm{X}_{1}=$ Total asset turn over, $\mathrm{X}_{2}=$ Inventori turn over, $\mathrm{X}_{3}=$ Fixed asset turn over, dan $\mathrm{X}_{4}=$ working capital turn over, $\mathrm{P}=$ Beta standardized, $\mathrm{e}_{2}=$ error .

Uji normalitas dengan menggunakan model Kolmogorov-Smirnov test dimaksudkan untuk 
menguji apakah nilai residual yang telah distandarisasi pada model regresi berdistribusi normal. Model telah berdistribusi normal jika nilai asymp.sig > alpha 5\%. Diperoleh Asymp. Sig 0,067 > 0,05. Ini berarti data berdistribusi normal.

Uji Linieritas dengan menggunakan metode Lagrange Multiplier (LM-Test).

LM-Test digunakan untuk mengukur linieritas yaitu dengan membandingkan nilai $\mathrm{X}^{2}$ hitung $\left(n \times R^{2}\right)$ dengan nilai $X^{2}$ tabel dengan $d f=(n, \alpha)$. Diperoleh nilai $\mathrm{R}^{2}$ sebesar 0,032 sehingga nilai $\mathrm{X}^{2}$ sebesar 0,032 x $111=3.552$ yang lebih kecil dari $\mathrm{X}_{\text {tabel }}$ dengan $\mathrm{df} 0,05,111$ sebesar 124,342. Dengan demikian dapat disimpulkan bahwa nilai $\mathrm{X}^{2}$ hitung $<$ nilai $\mathrm{X}^{2}$ tabel maka model regresi benar adalah linier.

\section{Uji Asumsi Klasik Substruktur 2}

Uji Multikolinieritas dengan menggunakan pendekatan nilai tolerance yang lebih besar dari 0,10 dan Variance Inflation Factor (VIF) tidak lebih dari 10. Diperoleh nilai Tolerance $>$ 0,10 dan nilai VIF $<10$. Ini berarti bahwa model regresi yang terbentuk tidak mengalami gejala miltikolinieritas. Uji Heteroskedastisitas dengan metode Glejser dilakukan dengan meregresikan semua variabel bebas terhadap nilai mutlak residualnya memiliki sig $>0,05$. Diperoleh hasil, bahwa variabel bebas tidak signifikan pada $\alpha=0,05$ terhadap nilai mutlak residualnya, model regresi tidak terjadi masalah heteroskedastisitas.

\section{Regresi linier berganda.}

\section{$\mathrm{Uj}$}

koefisien determinasi $\left(\mathrm{R}^{2}\right)$ menggambarkan besarnya kontribusi variabel bebas terhadap variabel tergantung. Makin tinggi koefisien determinasi, makin tinggi kemampuan variabel bebas menjelaskan variasi perubahan pada variabel tergantung. Hasil Model Summary menunjukkan bahwa model regresi yang digunakan menjelaskan pengaruh variabel bebas terhadap variabel tergantung sebesar $30,30 \%$ dan $83,49 \%$ berhubungan dengan variabel diluar model yang digunakan.

Uji $\mathrm{F}$ digunakan untuk menguji secara pengaruh variabel bebas terhadap variabel tergantung. Jika nilai $\mathrm{F}_{\text {hitung }}>\mathrm{F}_{\text {table, }}$ variabel bebas memiliki pengaruh secara simultan terhadap variabel tergantung dan model masuk dalam criteria cocok atau fit. Hasil Anova menunjukkan bahwa nilai $F_{\text {hitung }}(9.143)$ $>\mathrm{F}_{\text {tabel }}(2,643)$ pada alpha 5\%. Ini berarti bahwa model yang digunakan cocok untuk menjelaskan pengaruh variabel bebas terhadap variabel tergantung secara simultan.

Uji t. digunakan untuk menguji secara partial pengaruh variabel bebas terhadap variabel tergantung. Keberartian pengaruhnya ditunjukkan oleh besaran nilai thitung $>t_{\text {tabel }}$ pada alpha 5\%. Hasil penelitian menunjukkan bahwa variabel bebas ROA_Y1 memiliki nilai $t_{\text {hitung }}(6.009)>t_{\text {tabel }}(1,984)$ pada alpha $5 \%$. Ini menunjukkan bahwa variabel ROA_Y1 berpengaruh signifikan terhadap Peluang Investasi (Y2). Sedangkan variabel bebas lainnya, memiliki nilai $t_{\text {hitung }}<t_{\text {tabel }}$ pada alpha $5 \%$. Berdasarkan persamaan substruktur 2, diperoleh hasil pengujian hipotesis 2 , seperti pada Tabel 2

Tabel 2. Hasil Pengujian Hipotesis 2

\begin{tabular}{rrrrl}
\hline Variabel & P & T & Sig & Ket \\
\hline TATO_X1 & -0.103 & -0.997 & 0.331 & Ditolak \\
ITO_X2 & -0.039 & -0.469 & 0.640 & Ditolak \\
FATO_X3 & 0.166 & 1.657 & 0.101 & Ditolak \\
WCTO_X4 & -0.014 & -0.173 & 0.863 & Ditolak \\
ROA_Y1 & 0.543 & 6.009 & 0.000 & Diterima \\
\hline
\end{tabular}

Sumber : data diolah, 2019

Uji Regresi Variabel Mediasi.

Analisis regresi variabel mediasi dengan metode Product of Coefficient dilakukan dengan menguji kekuatan pengaruh tidak langsung variabel bebas $(\mathrm{X})$ terhadap variabel tergantung (Y2) melalui variabel mediasi (Y1). Uji signifikansi tidak langsung dilakukan berdasarkan rasio antara kosfisien (ab) dengan standard error yang akan menghasilkan nilai $\mathrm{Z}$ statistic. Jika nilai $\mathrm{Z}_{\mathrm{hitung}}=$ (ab) $/ \mathrm{S}_{\mathrm{ab}}>\mathrm{Z}_{\text {tabel }}$ pada $\alpha=0.05$, variabel mediasi berhasil memoderasi hubungan antara variabel bebas dengan variabel tergantung.

Pengaruh TATO (X1) terhadap Peluang Investasi melalui ROA $\left(\mathrm{Y}_{1}\right)$. Analisis regresi variabel mediasi dengan menggunakan metode Product of Coefficien, diperoleh nilai $\mathrm{Z}_{\text {hitung }} 3.4141>\mathrm{Z}_{\text {tabel }} 1.96$ berarti ROA $\left(\mathrm{Y}_{1}\right)$ berpengaruh signifikan dalam memediasi 
hubungan kausal antara TATO (X1) terhadap peluang investasi $\left(\mathrm{Y}_{2}\right)$.

Pengaruh ITO (X2) terhadap Peluang Investasi melalui ROA $\left(\mathrm{Y}_{1}\right)$. Analisis regresi variabel mediasi dengan menggunakan metode Product of Coefficien, diperoleh nilai $Z_{\text {hitung }} 0,06806<$ $\mathrm{Z}_{\text {tabel }} 1.96$ berarti ROA ( $\left.\mathrm{Y}_{1}\right)$ berpengaruh tidak signifikan dalam memediasi hubungan kausal antara ITO $\left(\mathrm{X}_{2}\right)$ terhadap peluang investasi $\left(\mathrm{Y}_{2}\right)$.

Pengaruh FATO (X3) terhadap Peluang Investasi melalui ROA (Y1). Analisis regresi variabel mediasi dengan menggunakan metode Product of Coefficien, diperoleh nilai $Z_{\text {hitung }} 1.93174<Z_{\text {tabel }} 1.96$ berarti ROA $\left(\mathrm{Y}_{1}\right)$ berpengaruh tidak signifikan dalam memediasi hubungan kausal antara FATO $\left(\mathrm{X}_{3}\right)$ terhadap peluang investasi $\left(\mathrm{Y}_{2}\right)$.

Pengaruh WCTO (X4) terhadap peluang investasi melalui ROA $\left(\mathrm{Y}_{1}\right)$. Analisis regresi variabel mediasi dengan menggunakan metode Product of Coefficien, diperoleh nilai $Z_{\text {hitung }} 1.2359<Z_{\text {tabel }} 1.96$ berarti ROA $\left(\mathrm{Y}_{1}\right)$ berpengaruh tidak signifikan dalam memediasi hubungan kausal antara WCTO (X4) terhadap peluang investasi $\left(\mathrm{Y}_{2}\right)$. Analisis regresi variabel mediasi, dapat dilakukan pengujian hipotesis 3 pada Tabel 3 berikut:

Tabel 3. Hasil Pengujian Hipotesis 3

\begin{tabular}{|c|c|c|c|}
\hline Variabel & $\begin{array}{l}\text { Nilai uji Z } \\
\text { pada } \alpha=0,05\end{array}$ & Signifikansi & Hipotesis 3 \\
\hline $\begin{array}{l}\text { TATOX1 - } \\
>Y 1->Y 2\end{array}$ & $\begin{array}{l}3.41410> \\
1,96\end{array}$ & Signifikan & Diterima \\
\hline $\begin{array}{l}\text { ITOX2 } \\
>Y 1->Y 2\end{array}$ & $\begin{array}{l}0.06806< \\
1.96\end{array}$ & $\begin{array}{l}\text { Tidak } \\
\text { Signifikan }\end{array}$ & Ditolak \\
\hline $\begin{array}{l}\text { FATO X3 - } \\
>Y 1->Y 2\end{array}$ & $\begin{array}{l}1.93174< \\
1.96\end{array}$ & $\begin{array}{l}\text { Tidak } \\
\text { Signifikan }\end{array}$ & Ditolak \\
\hline $\begin{array}{l}\text { WCTOX4- } \\
\text { >Y1->Y2 }\end{array}$ & $\begin{array}{l}1.23590< \\
1.96\end{array}$ & $\begin{array}{l}\text { Tidak } \\
\text { Signifikan }\end{array}$ & Ditolak \\
\hline
\end{tabular}

Sumber : data diolah, 2019

Berdasarkan analisis diatas, dapat digambarkan diagram jalur sebagai berikut:

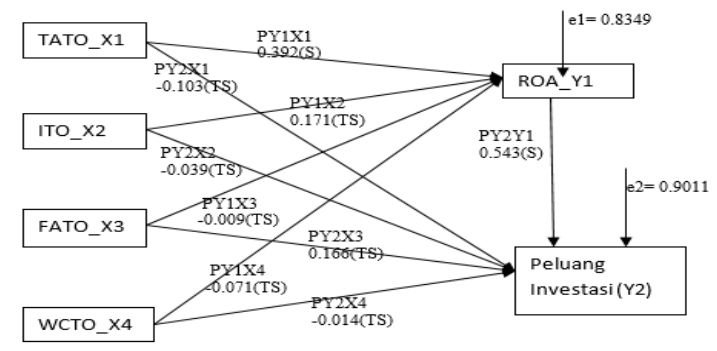

Gambar 1. Kerangka Analisis Jalur

Sumber : data diolah, 2019
Persamaan struktur dari model tersebut adalah:

Substruktur 1:

$\mathrm{Y}_{1}=0.392 \mathrm{X}_{1}+0.171 \mathrm{X}_{2}-0.009 \mathrm{X}_{3}-0.071 \mathrm{X}_{4}+$ 0.8389

Substruktur 2:

$\mathrm{Y}_{2}=-0.103 \mathrm{X}_{1}-0.039 \mathrm{X}_{2}+0.166 \mathrm{X}_{3}-0.014 \mathrm{X}_{4}+$ $0.543 Y_{1}+0.9011$

Pengaruh Total Asset Turn Over (TATO) terhadap Return on Asset (ROA)

TATO berpengaruh positif dan signifikan terhadap ROA. Ini berarti bahwa keberhasilan penggunaan total asset dalam meningkatkan penjualan berpengaruh signifikan terhadap kemampuan perusahaan dalam perolehan laba dari asset yang digunakan. Ini menunjukkan bahwa perusahaan berhasil melakukan efisiensi penggunaan asset dalam meningkatkan penjualan. Makin efisien penggunaan asset dalam meningkatkan penjualan, makin tinggi kemampuan perusahaan memperoleh laba. Adapun besaran pengaruh TATO terhadap ROA adalah $39.2 \%$ dan sisanya $77.97 \%$ berhubungan dengan variabel lain.

Pengaruh inventory turn over (ITO) terhadap return on asset (ROA).

ITO berpengaruh positif dan tidak signifikan terhadap ROA. Ini berarti bahwa keberhasilan penggunaan total inventory dalam mengefisiensikan harga pokok penjualan berpengaruh positive terhadap kemampuan perusahaan dalam perolehan laba dari asset yang dimiliki, namun tidak berpengaruh signifikan. Ini menunjukkan bahwa perusahaan berhasil melakukan efisiensi penggunaan dana pada persediaan namun keberhasilan tersebut tidak berpengaruh signifikan terhadap peningkatan kemampuan perusahaan memperoleh laba. Makin tinggi efisiensi pengunaan dana pada persediaan, makin tinggi kemampuan perusahaan memperoleh laba. Adapun besaran pengaruh ITO terhadap roa adalah $17,1 \%$ dan sisanya 91.05\% berhubungan dengan variabel lain. 
Pengaruh fixed asset turn over (FATO) terhadap return on asset (ROA).

FATO berpengaruh negatif dan tidak signifikan terhadap ROA. Ini berarti bahwa keberhasilan penggunaan fixed asset dalam meningkatkan penjualan berpengaruh negative dan tidak signifikan terhadap kemampuan perusahaan dalam perolehan laba dari asset yang dimiliki.Ini menunjukkan bahwa perusahaan tidak berhasil melakukan efisiensi penggunaan fexed asset dalam menghasilkan penjualan guna meningkatkan kemampuan perusahaan memperoleh laba. Makin tinggi efisiensi penggunaan fixed asset dalam menghasilkan penjualan, makin rendah kemampuan perusahaan memperoleh laba. Adapun besaran pengaruh FATO terhadap ROA adalah $-0.9 \%$ dan sisanya $100.44 \%$ berhubungan dengan variabel lain. Ini berarti kemampuan perusahaan dalam perolehan laba tidak dikarenakan peran fixed asset, tetapi lebih dikarenakan peran variabel lain diluar model.

Pengaruh working capital turn over (WCTO) terhadap return on asset (ROA).

WCTO berpengaruh negatif dan tidak signifikan terhadap ROA. Ini berarti bahwa keberhasilan penggunaan working capital dalam meningkatkan penjualan berpengaruh negatif dan tidak signifikan terhadap kemampuan perusahaan dalam perolehan laba dari asset yang dimiliki. Ini menunjukkan bahwa perusahaan tidak berhasil melakukan efisiensi penggunaan working capital dalam menghasilkan penjualan guna meningkatkan kemampuan perusahaan memperoleh laba. Makin tinggi efisiensi penggunaan working capital dalam menghasilkan penjualan, makin rendah kemampuan perusahaan memperoleh laba. Adapun besaran pengaruh WCTO terhadap ROA adalah $-7.1 \% \%$ dan sisanya $103.49 \%$ berhubungan dengan variabel lain. Ini berarti bahwa kemampuan perusahaan dalam perolehan laba tidak dikarenakan peran working capital, tetapi lebih dikarenakan peran variabel lain diluar model.
Pengaruh total asset turn over (TATO) terhadap Peluang Investasi.

TATO berpengaruh negative dan tidak signifikan terhadap peluang investasi. Ini berarti bahwa keberhasilan penggunaan total asset dalam meningkatkan penjualan berpengaruh negative dan tidak signifikan terhadap peluang investasi. Ini menunjukkan bahwa makin efisien penggunaan asset dalam meningkatkan penjualan, makin rendah peluang investasi. Adapun besaran pengaruh tato terhadap peluang investasi adalah $-10.3 \%$ dan sisanya $105.02 \%$ berhubungan dengan variabel lain. Ini berarti bahwa peluang investasi tidak dikarenakan peran efisensi penggunaan asset, tetapi lebih dikarenakan peran variabel lain diluar model.

Pengaruh inventory turn over (ITO) terhadap Peluang Investasi.

ITO berpengaruh negative dan tidak signifikan terhadap peluang investasi. Ini berarti bahwa keberhasilan penggunaan total inventory dalam mengefisiensikan harga pokok penjualan berpengaruh negatif dan tidak signifikan terhadap peluang investasi. Ini menunjukkan bahwa perusahaan dalam melakukan efisiensi penggunaan dana pada persediaan tidak berpengaruh signifikan dan negative terhadap peluang investasi. Makin tinggi efisiensi pengunaan dana pada persediaan, makin rendah peluang investasi. Adapun besaran pengaruh ITO terhadap peluang inveatsi adalah $-3.90 \%$ dan sisanya $101,93 \%$ berhubungan dengan variabel lain. Ini berarti bahwa peluang investasi tidak dikarenakan peran efisiensi penggunaan dana pada persediaan, tetapi lebih dikarenakan peran variabel lain diluar model.

Pengaruh fixed asset turn over (FATO) terhadap Peluang Investasi.

FATO berpengaruh positive dan tidak signifikan terhadap peluang investasi. Ini berarti bahwa keberhasilan penggunaan fixed asset dalam meningkatkan penjualan berpengaruh positive terhadap peluang investasi namun tidak signifikan. Ini menunjukkan bahwa perusahaan berhasil melakukan efisiensi penggunaan fexed asset dalam menghasilkan penjualan guna 
meningkatkan peluang investasi, namun peningkatkan efisiensi tersebut tidak berpengaruh signifikan terhadap peluang investasi. Makin tinggi efisiensi penggunaan fixed asset dalam menghasilkan penjualan, makin rendah peluang investasi. Adapun besaran pengaruh FATO terhadap peluang investasi adalah $16.6 \%$ dan sisanya $91.32 \%$ berhubungan dengan variabel lain.

Pengaruh working capital turn over (WCTO) terhadap Peluang Investasi.

WCTO berpengaruh negative dan tidak signifikan terhadap peluang investasi. Ini berarti bahwa keberhasilan penggunaan working capital dalam meningkatkan penjualan berpengaruh negative dan tidak signifikan terhadap peluang investasi. Ini menunjukkan bahwa perusahaan tidak berhasil melakukan efisiensi penggunaan working capital dalam menghasilkan penjualan guna meningkatkan peluang investasi. Makin tinggi efisiensi penggunaan working capital dalam menghasilkan penjualan, makin rendah peluang investasi. Adapun besaran pengaruh wcto terhadap peluang investasi adalah $-1.4 \%$ dan sisanya $100.7 \%$ berhubungan dengan variabel lain. Ini berarti bahwa peluang investasi tidak dikarenakan peran efisiensi penggunaan working capital, tetapi lebih dikarenakan peran variabel lain diluar model.

Pengaruh Profitabilitas (ROA) terhadap Peluang Investasi.

ROA berpengaruh positif dan signifikan terhadap peluang investasi. Ini berarti bahwa keberhasilan penggunaan total asset dalam meningkatkan laba bersih setelah pajak (EAT) berpengaruh signifikan terhadap peluang investasi. Ini menunjukkan bahwa perusahaan berhasil melakukan efisiensi penggunaan asset dalam menghasilkan eat. Makin efisien penggunaan asset dalam meningkatkan eat, makin tinggi peluang investasi. Adapun besaran pengaruh roa terhadap peluang investasi adalah $54.30 \%$ dan sisanya $67.60 \%$ berhubungan dengan variabel lain.
Pengaruh total asset turn over (TATO) terhadap Peluang Investas melalui ROA

Berdasarkan model product of coeffisien, diperoleh nilai $Z_{\text {hitung hubungan TATO }}$ terhadap peluang investasi melalui ROA sebesar $3.41410>$ nilai $Z_{\text {tabel }}=1,96$. Ini berarti bahwa ROA berpengaruh signifikan dalam memediasi hubungan TATO terhadap peluang investasi. Keberhasilan ROA dalam memediasi hubungan tato terhadap peluang investasi ditandai dari besarnya hubungan TATO terhadap $\mathrm{ROA}=0,391$ (signifikan) dan hubungan ROA terhadap peluang investasi 0.531 (signifikan).

Pengaruh InventoryTurn Over (ITO) terhadap Peluang Investasi melaui ROA.

Berdasarkan model product of coeffisien, diperoleh nilai $Z_{\text {hitung }}$ hubungan ITO terhadap peluang investasi melalui ROA sebesar $0.06806<$ nilai $\mathrm{Z}_{\text {tabel }}=1,96$. Ini berarti bahwa ROA berpengaruh tidak signifikan dalam memediasi hubungan ITO terhadap peluang investasi. Ketidak berhasilan ROA dalam memediasi hubungan ITO terhadap peluang investasi ditandai dari besarnya hubungan ITO terhadap $\mathrm{ROA}=0,166$ (tidak signifikan) dan hubungan ROA terhadap peluang investasi 0.540 (signifikan).

Pengaruh fixed asset turn over (FATO) terhadap Peluang Investasi melaui ROA.

Berdasarkan model product of coeffisien, diperoleh nilai $\mathrm{Z}_{\text {hitung }}$ hubungan FATO terhadap peluang investasi melalui roa sebesar 1.93174 $<$ nilai $\mathrm{Z}_{\text {tabel }}=1,96$. Ini berarti bahwa ROA berpengaruh tidak signifikan dalam memediasi hubungan FATO terhadap peluang investasi. Ketidak berhasilan ROA dalam memediasi hubungan FATO terhadap peluang investasi ditandai dari besarnya hubungan FATO terhadap ROA = 0,197 (tidak signifikan) dan hubungan ROA terhadap peluang investasi 0.507 (signifikan).

Pengaruh working capital turn over (WCTO) terhadap Peluang Investasi melaui ROA.

Berdasarkan model product of coeffisien, diperoleh nilai Zhitung hubungan WCTO terhadap peluang investasi melalui ROA 
sebesar $1.23590<$ nilai $Z_{\text {tabel }}=1,96$. Ini berarti bahwa ROA berpengaruh tidak signifikan dalam memediasi hubungan WCTO terhadap peluang investasi. Ketidakberhasilan ROA dalam memediasi hubungan WCTO terhadap peluang investasi ditandai dari besarnya nilai hubungan WCTO terhadap ROA $=-0.115$ (tidak signifikan) dan hubungan ROA terhadap peluang investasi 0.529 (signifikan).

\section{Kesimpulan}

Berdasarkan hasil dan pembahasan, dapat disimpulkan sebagai berikut: (1) Variabel aktivitas perusahaan berpengaruh signifikan terhadap kemampuan perusahaan memperoleh laba dari asset yang digunakan. Diantara variabel aktivitas: efisiensi penggunaan asset dalam meningkatkan penjualan berpengaruh signifikan terhadap kemampuan perusahaan memperoleh laba. Sedangkan efisiensi penggunaan dana pada inventory, efisiensi penggunaan asset tetap dan efisiensi penggunaan modal kerja tidak berpengaruh signifikan terhadap kemampuan perusahaan memperoleh laba; (2) Variabel aktivitas perusahaan berpengaruh signifikan terhadap peluang investasi. Diantara variabel aktivitas perusahaan: Kemampuan perusahaan memperoleh laba dari asset yang digunakan berpengaruh signifikan terhadap peluang investasi. Sedangkan efisiensi penggunaan asset, efisiensi penggunaan dana pada inventory, efisiensi penggunaan asset tetap dan efisiensi penggunaan modal kerja tidak berpengaruh signifikan terhadap peluang investasi; (3) Pengaruh aktivitas perusahaan: total asset turn over berpengaruh signifikan terhadap peluang investasi melalui return on asset. Sedangkan total inventory turn over, fixed asset turn over, working capital turn over tidak berpengaruh signifikan terhadap peluang investasi melalui return on asset.

\section{Saran}

Selanjutnya terdapat beberapa hal yang perlu peneliti sarankan, yaitu : (1) Peneliti selanjutnya dapat menggunakan variabel independen diluar model ini guna menjelaskan pengaruhnya terhadap peluang investasi secara lebih luas; (2) Bagi pelaku bisnis dalam mengambil keputusan investasi tidak hanya memperhatikan kemampuan perusahaan memperoleh laba tetapi juga hendaknya memperhatikan peluang investasi dimasa mendatang.

\section{Daftar Referensi}

Abrams, Jat H. 2010. Quantitative Business Valuation: A Mathematical Approach for Today's Professional, Second Edition, John Wiley \& Sons. Inc.

Alma, Buchari. 2001. Pengantar Bisnis, Edisi Revisi, Penerbit ALFABETE, Bandung.

Alwi, Syafaruddin, 1991. Alat Analisis dalam pembelanjaan, Edisi Revisi, Penerbit ANDI Offset, Yogtakarta.

Brealey, Richard A. Stewart C. Myers, 1991. Principles of Corporate Finance, Fourth Edition, McGraw-Hill, Inc. Singapore

Brigham, Eugene F., 1992. Fundamentals of Financial Management, Sixth Edition, The Dryden Press, Orlondo, Florida.

Ghozali, Imam, 2012. Partial Least Square: Konsep, Teknik dan Aplikasi Menggunakan Program Smart PLS 2.0M, Badan Penerbit Universitas Diponegoro, Semarang.

Halim, Abdul, 2015. Manajemen Keuangan Bisnis, Edisi Pertama, Mitra Wacana Media, Jakarta.

Hanafi, Mamduh M., dan Abdul Halim, 2016. Analisis Laporan Keuangan, Edisi Kelima, Penerbit UPP STIM YKPN, Yogyakarta.

Hery, 2017. Kajian Riset Akuntansi, Penerbit PT. Grasindo, Jakarta.

Fahmi, Irham, 2015. Analisis Laporan Keuangan, Penerbit ALFABETA Bandung.

Olobatuyi, Moses E, 2006. A User's Guide to Path Analysis, Lanham, Maryland: University Press of Amarica Inc.

Pardede Ratlan dan Renhard Manurung, 2014. Analisis Jalur (Path Analysis) Teori dan Aplikasi dalam Riset Bisnis, Penerbit Rineka Cipta, Jakarta.

Sukamulija, Sukmawati, 2017. Pengantar Pemodelan Keuangan dan Analisis Pasar Modal, Penerbit ANDI, Yogyakarta

Suliyanto, 2011. Ekonometrika Terapan: Teori dan Aplikasi dengan SPSS, Penerbit ANDI Yogyakarta.

Shapiro Alan C., 1991. Modern Corporate Finance, Machilian Publishing Company, New York. 
Titman, Sheidan, Arthur J. Keown, John D. Martin, 2018. Financil Management: Priciples and Application, Thirteenth Edition, Pearson Education Limited, United Kingdom.

www.idx.co.id 